Marquette University

e-Publications@Marquette

Economics Faculty Research and Publications

Economics, Department of

$11-9-2013$

\title{
A Note on War and Fiscal Capacity in Developing Countries
}

\author{
Abdur Chowdhury \\ Marquette University, abdur.chowdhury@marquette.edu \\ Syed M. Murshed \\ Coventry University
}

Published version. Peace Economics, Peace Science and Public Policy, Vol. 19, No. 3 (November 9, 2013): 431-435. DOI. (c) 2013 by Walter de Gruyter GmbH. Used with permission. 


\title{
Abdur R. Chowdhury and Syed Mansoob Murshed* A Note on War and Fiscal Capacity in Developing Countries
}

\begin{abstract}
We examine the effect of war on state fiscal capacity in developing countries, measured by tax revenue to GDP ratios. In divided or factionalised societies, patronage may substitute for common interest public goods, with the possibility of violent contestation over a rent. Our dynamic panel empirical estimates of the determinants of fiscal capacity are applied to 79 developing countries, during 1980-2010. Results indicate that war, especially civil war, retards fiscal capacity, along with poor governance, oil dependence and macroeconomic mismanagement.
\end{abstract}

Keywords: civil war, fiscal Capacity, developing countries

*Corresponding author: Syed Mansoob Murshed, Erasmus University - International Institute of Social Studies, Kortenaerkade 12 Den Haag 2518 AX, The Netherlands; and Coventry University, Priory Street, Coventry CV1 5FB, UK, E-mail: murshed@iss.nl

Abdur R. Chowdhury: Department of Economics, Marquette University, Milwaukee, WI 53201, USA

The functions of the state are important in maintaining societal cohesion and sustaining the social contract between rulers and ruled. Besides a legitimate Weberian monopoly over violence, a functioning state must be able to enforce laws, property rights and contracts, as well as have the capacity to raise revenues and provide public goods (Mill 1848). A modern state must also be able to provide a wider range of public goods (health, education for example), in addition to a capacity to regulate markets. More affluent nations have bigger governments (World Bank 2010), as measured by the share of government consumption in national income. Economic decline in 'failing' states undermines the state's fiscal capacity. Furthermore, a 'failing' state's ability to guarantee personal security, property rights and laws is seriously compromised, leading to the gradual privatisation of violence between predatory and defensive elements within society. Individuals rely on kinship based groups and warlords for security and public good provision; this in turn heightens the risk of civil war as society descends towards an anarchical state. In the contemporary developing world the lack of fiscal/state capacity enhances civil war risk; civil 
war in turn further attenuates fiscal capacity by undermining pre-existing fiscal institutions. State capacity is also essential for sustained growth with equity, which is the major challenge for developing countries. This requires that the state is able to command resources for its activities and public goods provision.

Curiously, war may have facilitated the development of state capacity in Europe since the $15^{\text {th }}$ century (Tilly 1992). Gradually, as wars became increasingly complex, requiring larger forces which had to be maintained for longer periods, other sources of finance (newer taxes or borrowing) had to be explored and invented. Increased taxation and conscription compelled rulers to make concessions to wider sections of the population. This meant more representative government, augmentation of state activities towards regulating production, manipulating distribution, providing social protection; in short more and more public goods. A history of making war against a nation's common external enemies may lay the foundations for future state capacity, and assist nation building, as it lays the basis for fiscal and legal institutions. This process, however, may not apply to internal conflict, which often undermines institutions, and interest in the provision of public goods.

Many developing countries commenced their post-colonial existence with reasonable institutions and state capacity. The last quarter of the $20^{\text {th }}$ century, however, witnessed growth and development failure in many parts of the developing world, especially in Africa. Associated with these developments, state capacity has declined, and several of these nations have also experienced civil war, which is widely believed to attenuate state capacity even further. Other developing countries, including those not experiencing civil war, are characterized by factional politics, with governments, even democratically elected ones, serving particular group interests. These states have little interest in providing common interest public goods to its entire citizenry, but will, instead, concentrate on using the state's resources to reward their own faction via political patronage. Patronage substitutes for wide ranging public goods. Thus, state capacity as measured by government expenditure as a proportion of national income may be low, but tax revenues as a share of national income will certainly be smaller in factionalized states where patronage is widespread; the state may also rely on overseas aid and its ability to directly command resources, royalties and rents for revenues.

We empirically analyze the effect of war, whose dominant form nowadays is civil war, on the fiscal capacity of the state in the contemporary developing world (between 1980 and 2010), measured by the tax/GDP ratio, which is our dependent variable. We do not look at government expenditure, because total 
state spending may be financed not only by taxation and borrowing, but also direct access to rents, royalties, state trading monopolies and foreign aid.

The state may also rely on inflation taxes, and manipulate the exchange rate to capture more resources for itself (we proxy this via a dual exchange rate variable). The rationale for using per capita GDP as one of the control variables is because richer nations tend to have better scores in governance indicators, and more solid and mature fiscal institutions.

We capture the nature of the state through governance variables. A poorly governed state, with weak institutions will have less fiscal capacity. The indicators of economic freedom (EFI from Gwartney and Lawson 2011) capture the likely impact of governance in the context of risk and prudential regulation prevailing in that country. They not only show how governments are elected, monitored and replaced, but also their capacity to formulate and implement public policies effectively as well as the attitude of the electorate and their representatives toward the institutions that govern economic, political, and social interactions. The conflict data are from UCDP (Themnér and Wallensteen 2011). Depending on the intensity of the conflict, we allow for three conflict categories: Low, Medium, and High corresponding to the alpha-numeric ranking 1, 2, and 3, respectively.

An important complication in empirically studying the impact of conflict on state capacity is the potential for endogeneity biases, reverse causation, and omitted variables. We try to address these concerns by using country and time fixed effects. In order to address biases due to reverse causality, we run regressions lagging all regressors one period, and we conduct dynamic system Generalized Method of Moments (GMM) estimations, using lagged regressors as instruments.

We test our model on a sample of 79 countries. The choice of countries is determined by the availability of consistent data on all the variables. The analysis uses a panel data set with data averaged over 5-year periods from 1980 to 2010. Full details can be found in Chowdhury and Murshed (2013).

A selection of some of the regression results in Chowdhury and Murshed (2013) are presented in Table 1. The presence of conflict is found to be costly in terms of a long-run reduction in fiscal capacity. Hence, any policy measures that would reduce the intensity of conflict would go a long way in enhancing the revenue capability in the developing countries. Dual (distorted) exchange rates, inflation and openness all impact negatively and significantly on tax capacity. We also examine the impact of ethnic fractionalisation on the state's fiscal capacity by including an index of ethno-linguistic fragmentation (Alesina et al. 2003). In column 3 of Table 1, the variable turns out to be negative and statistically significant. We also add an oil and gas exporter dummy; oil exporting countries appear less dependent on domestic resource mobilization. 
Table 1: System GMM estimation results: ethnicity \& oil and gas exporter dummy.

\begin{tabular}{|c|c|c|c|c|c|}
\hline Variable & $\begin{array}{r}\text { Base } \\
\text { equation }\end{array}$ & Ethnicity & Ethnicity & Oil/Gas & Oil/Gas \\
\hline Constant & $12.24(6.20)$ & $6.22(3.45)$ & $7.15(3.91)$ & $4.70(2.56)$ & $3.66(2.90)$ \\
\hline Conflict & $-1.84(5.63)$ & - & - & - & - \\
\hline $\log (G D P P C)$ & $0.54(3.74)$ & $0.45(2.68)$ & $0.64(3.14)$ & $0.31(2.96)$ & $0.70(3.03)$ \\
\hline $\log (G D P)$ & $0.78(2.94)$ & $2.44(5.34)$ & $1.80(3.96)$ & $1.98(5.76)$ & $1.04(3.80)$ \\
\hline Inflation & $-1.20(4.12)$ & $-0.65(2.65)$ & $-1.02(4.40)$ & $-1.50(3.70)$ & $-1.94(3.70)$ \\
\hline Dual ex rate & $-1.33(4.59)$ & $-0.87(3.90)$ & $-1.15(4.16)$ & $-1.12(4.39)$ & $-1.35(3.66)$ \\
\hline Trade & $-0.49(3.23)$ & $-1.54(4.10)$ & $-0.63(3.80)$ & $-0.76(3.87)$ & $-0.85(2.38)$ \\
\hline $\mathrm{EFI}$ & $3.90(7.42)$ & $2.35(5.54)$ & $2.40(6.60)$ & $2.75(6.10)$ & $1.80(4.33)$ \\
\hline Ethnicity & - & $-0.74(1.11)$ & $-0.82(2.04)$ & - & - \\
\hline Oil/Gas dummy & - & - & - & $-1.12(3.46)$ & $-2.64(4.15)$ \\
\hline Africa*conflict & $-0.08(2.00)$ & $-0.43(3.72)$ & $-0.36(2.14)$ & $-0.64(3.65)$ & $-0.49(3.04)$ \\
\hline Ethnicity* conflict & - & $0.65(1.45)$ & - & - & - \\
\hline Oil/Gas* conflict & - & - & - & $-0.18(2.35)$ & - \\
\hline $\begin{array}{l}1^{\text {st }} \text { order serial corr. } \\
\text { (p-value) }\end{array}$ & 0.06 & 0.10 & 0.04 & 0.10 & 0.07 \\
\hline $\begin{array}{l}2^{\text {nd }} \text { order serial corr. } \\
\text { (p-value) }\end{array}$ & 0.43 & 0.22 & 0.18 & 0.27 & 0.34 \\
\hline Years indicator & Yes & Yes & Yes & Yes & Yes \\
\hline Country fixed effect & Yes & Yes & Yes & Yes & Yes \\
\hline$A R(1) p$-value & 0.014 & 0.009 & 0.008 & 0.011 & 0.017 \\
\hline$A R(2) p$-value & 0.336 & 0.190 & 0.236 & 0.202 & 0.226 \\
\hline $\begin{array}{l}\text { Hansen test for } \\
\text { Overidentifying } \\
\text { restrictions ( } p \text {-value) }\end{array}$ & $14.68(0.18)$ & $13.11(0.17)$ & $12.84(.12)$ & $9.35(0.11)$ & $11.14(0.13)$ \\
\hline Sargan test ( $p$-value) & 0.26 & 0.12 & 0.17 & 0.12 & 0.17 \\
\hline $\begin{array}{l}\text { Difference Sargan } \\
\text { test (p-value) }\end{array}$ & 0.24 & 0.19 & 0.20 & 0.22 & 0.22 \\
\hline Number of countries & 79 & 79 & 79 & 76 & 76 \\
\hline $\begin{array}{l}\text { Number of } \\
\text { observations }\end{array}$ & 510 & 510 & 510 & 480 & 480 \\
\hline
\end{tabular}

Figures in parentheses after the coefficient estimates are the absolute values of the t-statistics.

We find that war, which is dominantly civil war, does not promote the fiscal capacity of the state in contemporary developing countries, unlike the findings of Charles Tilly for inter-state war in European history. This may be attributable to the destructive influence of civil war on political and economic institutions, as well as the possibility that civil war is symptom of the lack of common interest public goods. Ultimately, however, Charles Tilly may have got it right - state building remains a quasi-criminal activity - a process which may not necessitate 
the development of fiscal capacity as long as alternative sources of coercive resource extraction remain available to those who govern.

Previously published online November 9, 2013

\section{References}

Alesina, Alberto, Devleeschauwer, Arnaud, Easterly, William, Kurlat, Sergio, Wacziarg, Romain, (2003), Fractionalization, Journal of Economic Growth, vol. 8, no. 2, pp. 155-194.

Chowdhury, Abdur Rahim, Murshed, S. Mansoob, (2013), War and the Fiscal Capacity of the State, Department of Economics, Marquette University, WP 2013-02.

Gwartney, J.D., Lawson, R.A., (2011), Economic Freedom of the World: Annual Report, Fraser Institute, Vancouver, British Columbia.

Mill, John Stuart, (1848), Principles of Political Economy, Reprinted 1998 as Oxford Classics paperback.

Themnér, Lotta, Wallensteen, Peter, (2011), Armed Conflict, 1946-2010, Journal of Peace Research, vol. 48, no. 4, pp. 525-536.

Tilly, Charles, (1992), Coercion, Capital and European States, AD 990-1992, Blackwell, Cambridge, MA.

World Bank, (2010), Financial Structure and Economic Development Database (November, 2010). 